\title{
UPAYA PENGGUNAAN PERANGKAT MULTIMEDIA DALAM MENINGKATKAN MOTIVASI BELAJAR SISWA-SISWI KELAS VIII PADA MATA PELAJARAN SEJARAH KEBUDAYAAN ISLAM DI MADRASAH TSANAWIYAH AL-MU'IN KOTA TANGERANG
}

\author{
Ajiz Guntur \\ ajizguntur73@gmail.com \\ Kantor Kementrian Agama Kota Tangerang Provinsi Banten
}

\begin{abstract}
The problem raised in this study is how to use multimedia tools to increase student motivation in class VIII MTs Al Mu'in Tangerang City in the subject of Islamic cultural history. While the purpose of this study is to find out how to use multimedia devices, choose multimedia devices, and assess the effectiveness of using multimedia devices in the learning process, related to school efforts in increasing the learning motivation of students in the classroom. The method used in this research is to use the observation method, interview method, and documentation method. Meanwhile, to analyze the results of this study, qualitative descriptive analysis is used which consists of three activities, namely data collection as well as data reduction, data presentation and conclusions or verification. It is known that the use of multimedia devices at Mts Al-Mu'in Tangerang City in increasing learning motivation is by means of teachers using and combining methods of lectures, discussions, and the use of multimedia devices in the form of projectors, videos, and visual media even though the use of multimedia devices at MTs AlMu'in at this point is not so significant because of the limitations of the multimedia device itself.
\end{abstract}

Keywords: Efforts to Use Multimedia Devices, Increase Motivation, Student Learning.

\begin{abstract}
ABSTRAK
Permasalahan yang diangkat dalam penelitian ini adalah, bagaimana upaya penggunaan perangkat multimedia dalam meningkatkan motivasi belajar siswa di kelas VIII MTs Al-Mu'in Kota Tangerang pada mata pelajaran sejarah kebudayaan islam. Sedangkan tujuan penelitian ini ialah untuk mengetahui bagaimana penggunaan perangkat multimedia, memilih perangkat multimedia, dan mengkaji efektifitas penggunaan perangkat multimedia dalam proses pembelajaran, terkait dengan usaha sekolah dalam meningkatkan motivasi belajar peserta didiknya di dalam kelas. Metode yang digunakan dalam penelitian ini ialah dengan menggunakan metode observasi, metode wawancara, dan metode dokumentasi. Sedangkan untuk menganalisis hasil penelitian ini, digunakan analisis deskriptif kualitatif yang terdiri dari tiga kegiatan yaitu pengumpulan data sekaligus reduksi data, penyajian data dan kesimpulan atau verifikasi. Diketahui bahwa penggunaan perangkat multimedia di MTs. AlMu'in Kota Tangerang dalam meningkatkan motivasi belajar adalah dengan cara guru menggunakan dan memadukan metode ceramah, diskusi, dan penggunaan perangkat multimedia berupa proyektor, video, dan media visual meski penggunaan perangkat multimedia di MTs. Al-Mu'in pada saat ini belum begitu signifikan karena adanya keterbatasan dari perangkat multimedia itu sendiri.
\end{abstract}


Kata Kunci: Upaya Penggunaan Perangkat Multimedia, Meningkatkan Motivasi, Belajar Siswa.

\section{Pendahuluan}

Pendidikan menurut undang-undang Pendidikan Nasional No. 20 tahun 2003 bahwa pendidikan adalah usaha sadar dan terencana untuk mewujudkan suasana belajar dan proses pembelajaran agar siswa secara aktif mengembangkan potensi dirinya untuk memiliki kekuatan spiritual keagamaan, pengendalian diri, kepribadian, kecerdasan akhlak mulia, keterampilan yang diperlukan dirinya, masyarakat, bangsa dan Negara. Dengan adanya pendidikan seseorang dapat mengembangkan potensi yang dimilikinya sehingga akan memiliki ilmu pengetahuan yang bermanfaat untuk kehidupannya didalam AL-Qur'an dijelaskan bahwa Allah SWT akan mengangkat derajat orang yang berilmu pengetahuan (QS. AlMujadalah [58]: 11). ${ }^{1}$

Perkembangan ilmu pengetahuan yang begitu pesat seperti saat ini telah memicu tumbuhnya revolusi yang besar pada kemajuan dunia. Salah satunya ditandai dengan begitu banyaknya penemuan yang diciptakan oleh manusia dalam bentuk teknologi. Berbagai media pembelajaran sudah mulai diterapkan disekolah, salah satunya multimedia berbasis computer. Teknologi pendidikan berupa multimedia ini merupakan salah satu media pembelajaran, yang dapat dimanfaatkan oleh guru untuk mempermudah jalannya proses pendidikan. Dengan segala kemudahan yang dimiliki, membuat media pembelajaran tersebut menjadi salah satu media yang dipilih oleh guru untuk menyampaikan materi pelajaran di dalam kegiatan belajar

${ }^{1}$ Departemen Agama RI Al-Qur'an dan Terjemahannya Juz 1-30 Edisi Terbaru, Mekar Surabaya, No. BD. III/TL. 02.1/339/2004. Surabaya. mengajar. Media pembelajaran adalah alat atau bentuk stimulus yang berfungsi untuk menyampaikan pesan pembelajaran. ${ }^{2}$

Media pembelajaran dalam hal ini merupakan bagian dari proses pembelajaran, karena berhubungan langsung dengan pemberian materi pelajaran dalam rangka efektifitas dan efisiensi pengajaran. Media pembelajaran yang digunakan harus memenuhi persyaratan tertentu, baik itu edukatif, teknis, maupun persyaratan lainnya. Persyaratan dalam standard ini perlu ditetapkan karena alat peraga atau media. Media pembelajaran yang dapat digunakan dalam proses belajar mengajar banyak sekali, begitu juga dalam pembelajaran SKI juga bisa menggunakan banyak sekali media pembelajaran. Media yang dimanfaatkan dalam pembelajaran SKI antara lain: komputer/laptop, LCD proyektor, dan sebagainya. Media-media tersebut mempunyai karakteristik tersendiri, sehingga dapat memudahkan dalam mempelajari mata pelajaran SKI. Salah satu alternatife yang bisa dilakukan dalam menumbuhkan minat atau motivasi belajar siswa pada materi Sejarah Kebudayaan Islam yaitu dengan penggunaan multimedia. Media pembelajaran memiliki bentuk yang bermacam-macam, dari media sederhana sampai yang kompleks. Perkembangan teknologi dan informasi juga ikut menyumbang semakin kayanya media pembelajaran yang bisa dimanfaatkan oleh seorang guru. Kekomplekan komponen yang ada dalam teknologi baik dari segi audio, visual dan kinetestik memberikan wadah terhadap karakteristik belajar peserta didik. Setiap media tentunya

${ }^{2}$ Ruswan, Belajar dan Pembelajaran Berbasis Komputer (Bandung; Alfa Beta, 2012) h.143. 
memiliki kelebihan dan kekurangan, untuk itu dalam pemakaiannya harus mempertimbangkan karakteristik materi yang diajarkan, tujuan intruksional yang harus dicapai dan juga mempertimbangkan jenis belajar siswa agar media pembelajaran yang digunakan berfungsi secara optimal dalam meningkatkan mutu belajar siswa. Seperti halnya dalam AlQur'an menjelaskan bahwasannya segala informasi yang didapat melalui media. lihat (QS. An-Nahl[16]: 44). ${ }^{3}$

Pembelajaran di sekolah banyak yang dibuat, baik atas insiatif guru sesuai dengan silabus mata pelajaran tersebut, alat penghubung dalam proses interaksi belajar mengajar untuk meningkatkan efektifitas hasil belajar, maka harus di sesuaikan dengan orientasi dan tujuan pembelajaran. Ada beberapa alasan berkenaan dengan pemilihan teknologi pendidikan sebagai media pembelajaran. Diantaranya pelajaran akan lebih menarik perhatian peserta didik, bahan pelajaran akan lebih mudah dipahami oleh siswa, metode pembelajaran akan lebih bervariasi, dan peserta didik akan lebih banyak melakukan kegiatan belajar. Bahkan penggunaan media akan mempertinggi kualitas proses dan hasil pembelajaran. Multimedia merupakan salah satu teknologi pendidikan yang dapat menghadirkan visualisasi dari materi pelajaran. ${ }^{4}$

Salah satu metode yang banyak dipergunakan oleh guru adalah dengan menggunakan metode ceramah, termasuk dalam penyampaian pelajaran Sejarah Kebudayaan Islam. Dalam peraktek dilapangan penggunaan metode ini tidak selamanya berhasil, sehingga kadang-

${ }^{3}$ Departemen Agama RI Al-Qur'an dan Terjemahannya Juz 1-30 Edisi Terbaru, Mekar Surabaya, No. BD. III/ TL. 02.1/339/2004. Surabaya.

${ }^{4}$ Sudjana Nana dkk, Media Pengajaran (Bandung: Sinar Baru Algen Sindo, 2001) h. 2. kadang menimbulkan perasaan bosan dan lelah. Hal ini dapat mengurangi motivasi belajar anak. Menurut Bimo Walgito dalam buku Pengantar Psikologi Umum mengatakan:" motivasi merupakan komponen yang sangat penting dalam melakukan suatu kegiatan, motivasi dapat memberikan suara dorongan dan mengarahkan perilaku seseorang menuju yang baik". 5

Motivasi merupakan gejala psikologi yang terbagi menjadi dua bentuk yaitu: motivasi intrinsik adalah dorongan yang berasal dari dalam diri sendiri atau menyatu dengan tugas yang dilakukannya dan motivasi ekstrinsik adalah dorongan yang datang dari luar diri seseorang yang tidak berkaitan dengan tugas yang dilakukannya. ${ }^{6}$ Penggunaan multimedia dalam upaya meningkatkan motivasi belajar peserta didik, mendorong penulis untuk mengadakan penelitian yaitu berbentuk pembelajaran yang menggunakan perpaduan antara, media video dan media visual. Sebab teknologi ini sudah dianggap sebagai sesuatu yang harus di pakai di dalam pembelajaran di era globalisasi pada saat ini. Tidak bisa dipungkiri bahwa teknologi multimedia memberi kesan yang besar dalam bidang media pembelajaran karena bisa menginteraksikan teks, grafik, animasi, audio dan video. Multimedia telah mengembangkan proses pengajaran dan pembelajaran kearah yang lebih dinamik. Namun yang lebih penting ialah pemahaman tentang bagaimana menggunakan teknologi tersebut dengan lebih efektif dan dapat menghasilkan ideide untuk pengajaran dan pembelajaran. Pada masa kini, guru mempunyai

${ }^{5}$ Bimo Walgito, Pengantar Psikologi Umum,(Yogyakarta: Andi Afset, 2004) Cet. Ke-4 h. 140-142

${ }^{6}$ Rintyastini, Bimbingan Konseling SMP (Surabaya: Erlangga, 2008) h. 85. 
kemahiran dan keyakinan diri dalam menggunakan teknologi ini dengan cara yang yang paling berkesan. Suasana pengajaran dan pembelajaran dan pembelajaran yang interaktif, lebih menggalakan komunikasi aktif antara berbagai hal. Penggunaan komputer multimedia dalam proses pengajaran dan pembelajaran adalah dengan tujuan meningkatkan mutu pengajaran dan pembelajaran.

MTS Al-Mu'in Tangerang juga merupakan salah satu sekolah yang pembelajarannya menggunakan multimedia. Pembelajaran yang berpusat pada siswa dimungkinkan siswa membangun pengetahuannya sendiri baik secara mandiri maupun dengan bantuan pendidik. Semua itu dilaksanakan dalam upaya meningkatkan mutu pembelajaran di MTs. Al-Mu' in Kota Tangerang dan sebagai upaya agar motivasi siswa dalam belajar meningkat.

Berdasarkan hal tersebut diatas, peneliti ingin mengetahui Peran perangkat multimedia dalam meningkatkan motivasi belajar siswa di Madrasah Tsanawiyah AlMu'in Kota Tangerang, khususnya pada mata pelajaran Sejarah Kebudayaan Islam.

\section{Kajian Teori}

A. Multimedia Pembelajaran

1. Definisi Multimedia

Media berasal dari kata "medium" yang berarti perantara, sementara multimedia diambil dari kata multi dan media. Multi berarti banyak dan media berarti media atau perantara. multimedia juga mempunyai komunikasi interaktif yang tinggi. Bagi pengguna komputer multimedia dapat diartikan sebagai informasi komputer yang dapat disajikan melalui audio atau video, teks, grafik, dan animasi. Disini dapat digambarkan bahwa multimedia adalah suatu kombinasi data atau media untuk menyampaikan suatu informasi sehingga informasi itu tersaji dengan lebih menarik. ${ }^{7}$

Banyak definisi tentang konsep multimedia, salah satunya Vaughan mendefinisikan multimedia sendiri terdiri atas elemen-elemen teks, gambar/foto, seni grafis, suara, animasi, dan elemen-elemen video yang dimanipulasi secara digital. Umumnya, dalam definisi tentang multimedia disebutkan bahwa karakteristik multimedia terdiri atas elemen-elemen teks, grafik, animasi, video, dan suara yang terintegrasi, serta konten yang dapat di susun dan dipersentasikan secara berbeda. ${ }^{8}$ Zulkifli mengatakan di dalam bukunya multimedia didefinisikan sebagai komunikasi yang menggunakan kombinasi antara berbagai media yang berbeda, dan mungkin melibatkan komputer di dalamnya. ${ }^{9}$

Multimedia terbagi menjadi dua kategori, yaitu: multimedia linier dan multimedia interaktif. Multimedia linier adalah salah suatu multimedia yang tidak dilengkapi dengan alan pengontrl ataupun yang dapat dioperasikan oleh pengguna. Multimedia ini berjalan sekuensial (berurutan), contohnya: TV dan film. ${ }^{10}$ Multimedia interaktif adalah suatu multimedia yang dilengkapi dengan alat pengontrol yang dapat dioperasikan oleh pengguna, sehingga pengguna dapat memilih apa yang dikehendaki untuk prose selanjutnya. Conntoh multimedia interaktif adalah pembelajaran interaktif, aplikasi game, dan lain-lin. Multimedia

${ }^{7}$ Kadaruddin, Buku Referensi Media dan Multimedia Pembelajaran, Penerbit Deepublish Yogyakarta 2016 h. 81.

${ }^{8}$ Muhammad Rusli, Dadang Hermawan, dan Ni Nyoman Supuwaningsih, Multimedia Pembelajaran yang Inovatif, CV Andi Offset Jl. Beo 38-40, Yogyakarta 2017 h. 1.

${ }^{9}$ Zulkifli, Media Pembelajaran, Bias Cemerlang Kota Tangerang 2018 h. 108.

${ }^{10}$ Daryanto, Media Pembelajaran Edisi Ke-2 Revisi, Gava Media Yogyakarta 2016 h. 69. 
dimanfaatkan juga dalam dunia pendidikan. Di dunia pendidikan, multimedia digunakan sebagai media pembelajaran, baik dalam kelas maupun secara sendiri-sendiri. ${ }^{11}$

Sedangkan pembelajaran diartikan sebagai proses penciptaan lingkungan yang memungkinkan terjadinya proses belajar. Jadi dalam pembelajaran yang utama adalah bagaimana siswa belajar. Belajar dalam pengertian aktifitas mental siswa dalam berinteraksi dengan lingkungan yang menghasilkan perubahan perilaku yang bersifat relative konstan. Dengan demikian aspek yang menjadi penting dalam aktifitas belajar adalah lingkungan. Bagaimana lingkungan ini diciptakan dengan menata unsur-unsurnya sehingga dapat mengubah perilaku siswa.

\section{B. Karakteristik Multimedia}

Sebagai salah satu komponen sistem pembeljaran, pemilihan dan penggunaan multimedia pembelajaran harus memperhatikan karakteristik komponen lain, seperti: tujuan, materi, strategi dan juga evaluasi pembelajaran.

Karakteristik multimedia pembelajaran adalah sebagai berikut:

1. Memiliki lebih dari satu media yang konvergen, misalnya menggabungkan unsur audio dan visual

2. Bersifat interaktif, dalam pengertian memiliki kemampuan untuk mengakomodasi respon pengguna.

3. Bersifat mandiri, dalam pengertian memberi kemudahan dan kelengkapan isi sedemikian rupa sehingga pengguna bisa menggunakan tanpa bimbingan orang lain.

Selain memenuhi ketiga karakteristik tersebut, multimedia pembelajaran

\footnotetext{
${ }^{11}$ Kadaruddin, buku referensi Media dan Multimedia Pembelajaran, Penerbit Deepublish Ypgyakarta 2016 h. 82
}

sebaiknya juga memnuhi fungsi sebagai berikut:

a. Mampu memperkuat respon pengguna secepatnya dan sesering mungkin,

b. Mampu memberikan kesempatan kepada siswa untuk mengontrol laju kecepatan belajarnya sendiri,

c. Memperhatikan bahwa siswa mengikuti suatu urutan yang jelas dan terkendalikan.

Mampu memberikan kesempatan adanya partisipasi dari pengguna dalam bentuk respon, baik berupa jawaban, pemilihan, keputusan percobaan dan lainlain. $^{12}$

\section{Format Multimedia}

Format sajian multimedia pembelajaran dapat dikategorikan ke dalam lima kelompok sebagai beriut;

a. Tutorial. Format sajian ini merupakan multimedia pembelajaran yang dalam penyampaian materinya dilakukan secara tutorial, sebagaimana layaknya tutorial yang dilakukan oleh guru atau instruktur. Informasi yang berisi suatu konsep disajikan dengan teks, gambar, baik diam atau bergerak. Pada saatb yang tepat, yaitu ketika dianggap bahwa pengguna telah membaca, menginterpretasikan dan menyerap konsep itu, diajukan serangkaian pertanyaan atau tugas. Jika jawaban atau respon pengguna benar, kemudian dilanjutkan dengan materi berikutnya. Jika jawaban atau respon pengguna salah, maka pengguna harus mengulang memahami konsep tersebut secara keseluruhan ataupun pada bagian-bagian tertentu saja (remedial). kemudian pada bagian akhir biasanyaakan diberikan serangkaian pertanyaan yang merupakan tes untuk

\footnotetext{
${ }^{12}$ Daryanto, Media Pembelajaran Edisi Ke-2 Revisi, Gava Media Yogyakarta 2016 h. 71-72.
} 
mengukur tingkat pemahaman pengguna atas konsep atau materi yang disampaikan.

b. Drill dan Practise. Format ini dimaksudkan untuk melatih pengguna sehingga mempunyai kemahiran di dalam suatu keterampilan atau memperkuat penguasaan terhadap suatu konsep. Program ini juga menyediakan serangkaian soal atau pertanyaan yang biasanya ditampilkan secara acak, sehingga setiap kali digunakan maka soal atau pertanyaan yang tampil akan selalu berbeda, atau paling tidak dalam kombinasi yang berbeda, Program ini juga dilengkapi dengan jawaban yang benar, lengkap dengan penjelasannya sehingga diharapkan pengguna akan bisa pula memahami suatu konsep tertentu. Pada bahagian akhir, pengguna juga bisa melihat skor akhir yang dia capai, sebagai indikator untuk mengukur tingkat keberhasilan dalam memecahkan soal-soal yang diajukan.

c. Simulasi. Multimedia pembelajaran dengan format ini mencoba menyamai proses dinamis yang terjadu di dunia nyata, misalnya untuk mensimulasikan pesawat terbang, di mana pengguna seolah-olah melakukan aktifitas menerbangkan pesawat terbang, menjalankan usaha kecil, atau pengendalian pembangkit listrik tenaga nuklir dan lain-lain. Pada dasarnya format ini mencoba memberikan pengalaman masalah dunia nyata yang biasanya berhubungan dengan suatu resiko, seperti pesawat yang akan jatuh atau menabrak, perusahaan akan bangkrut, atau terjadi malapetaka nuklir.

d. Percobaan atau Eksperimen. Format ini mirip dengan format simulasi, namun lebih ditujukan pada kegiatan-kegiatan yang bersifat eksperimen, seperti kegiatan praktikum di laboratorium IPA, biologi atau kimia. Program menyediakan serangkaian peralatan dan bahan, kemudian pengguna bisa melakukan percobaan atau eksperimen sesuai petunjuk dan kemudian mengembangkan eksperimeneksperimen lain berdasarkn petunjuk tersebut. Diharapkan pada akhirnya pengguna dapat menjelaskan suatu konsep atau fenomena tertentu berdasarkan eksperimen yang mereka lakukan secara maya tersebut.

e. Permainan.Tentu saja bentuk permainan yang disajikan di sini tetap mengacu pada proses pembelajaran dan dengan program multimedia berformat ini diharapkan terjadi aktifitas belajar sambil bermain. Dengan demikian pengguna tidak merasa bahwa mereka sesungguhnya sedang belajar. Media pembelajaran yang menggunakan banyak media, dikenal sebagai media pembelajaran berbasis multimedia, dapat dibuat dengan menggunakan banyak perangkat lunak yang dapat untuk mengolah teks, seperti Microsoft Office Family atau Note Pad; mengolah gambar seperti Corel Draw, Microsoft Visio, Adobe Photosop dan lain-lain; mengolah animasi baik animasi teks ataupun animasi gambar seperti Macromedia Family (Flash, Freehand, Authorware, Dreamweaver), 3D Max, Swish dan lain-lain; mengolah suara seperti Cool Edit Pro, Audio Studio, dan lain-lain; mengolah video seperti Windows Moviemaker, VCD Cutter dan lain-lain dan digabungkan menjadi satu dengan program-program Authoring (authoring tool) seperti Macromedia Authorware, Dreamweaver, Visual Basic, Delphi dan lain-lain. Media pembelajarab berbasis multimedia haruslah mudah digunakan yang memuat navigasi- 
navigasi sederhana yang memudahkan pengguna. Selain itu harus menarik agar merangsang pengguna tertarik menjelajah seluruh program, sehingga seluruh materi pembelajaran yang terkandung di dalamnya juga harus disesuaikan dengan kebutuuhan pengguna, sesuai dengan kurikulum dan mengandung banyak manfaat. Media pembelajaran berbasis multimedia tersebut juga harus mudah peng-install-annya pada komputer, serta tidak memerlukan CD dalam menjalankannya. Karena dengan kemudahan tersebut membuat pengguna merasa lebih praktis dan penyebarannya akan lebih luas. ${ }^{13}$

\section{Media Visual}

Media berbasis visual (image atau perumpamaan) memegang peran yang sangat penting dalam proses belajar. Media visual dapat memperlancar pemahaman (misalnya melalui elaborasi struktur dan organisasi) dan memperkuat ingatan. Visual dapat pula menumbuhkan minat siswa dan dapat memberikan hubungan antara isi materi pelajaran dengan dunia nyata. Agar menjaddi efektif, visual sebaiknya ditempatkan pada konteks yang bermakna dan siswa harus berinteraksi dengan visual (image) itu untuk meyakinkan terjadinya proses informasi. ${ }^{14}$

Bentuk visual bisa berupa: (a) gambar representasi seperti gambar, lukisan atau foto yang menunjukan bagaimana ntampaknya sesuatu benda; (b) diagram yang melukiskan hubunganhubungan konsep, organisasi, dan struktur isi material; (c) peta yang menyajikan gambaran/kecenderungan data atau antar hubungan seperangkat gambar atau angka-

\footnotetext{
${ }^{13}$ Daryanto, Media Pembelajaran Edisi Ke-2 Revisi, Gava Media Yogyakarta 2016 h. 72-74

${ }^{14}$ Zulkifli, Media Pembelajaran, Bias Cemerlang Kota Tangerang 2018 h. 77.
}

angka. Ada beberapa prinsip umum yang perlu diketahui untuk penggunaan efektif media berbasis visual sebagai berikut.

1) Usahakan visual itu sesederhana mungkin dengan menggunakan gambar garis, karton, bagan, dan diagram. Gambar realistis harus digunakan secara hati-hati karena gambar yang amat rinci dengan realisme sulit diproses dan dieplajari bahkan seringkali mengganggu perhatian siswa untuk mengamai apa yang seharusnya diperhatikan.

2) Visual digunakan untuk menekankan informasi sasaran (yang terdapat teks) sehingga pembelajaran dapat terlaksana dengan baik

3) Gunakan grafik untuk menggambarkan iktisar keseluruhan materi sebelum menyajikan unit demi unit pelajaran untuk digunakan leh siswa mengorganisasikan informasi,

4) Ulangi sajian visual dan libatkan siswa untuk meningkatkan daya ingat. Meskipun sebagian visual dapat dengan mudah diperoleh informasinya, sebagian lagi memerlukan pengamatan dengan hatihati. Untuk visual yang kompleks siswa perlu diminta untuk mengamatinya, kemudian mengungkapkan sesuatu mengenai visual tersebut setelah menganalisis dan memikirkan informasi yang terkandung dalam visual itu. Jika perlu, siswa diarahkan kepada informasi penting secara rinci.

5) Gunakan gambar untuk melukiskan perbedaan konsep-konsep, misalnya dengan menampilkan konsep-konsep yang divisualkan itu secara berdampingan.

6) Hindari visual yang tak-berimbang.

7) Tekankan kejelasan dan ketetapan dalam semua visual. 
8) Visual yang diproyeksikan harus dapat terbaca dan mudah dibaca.

9) Visual, khususnya diagram, amat membantu untuk mempelajari materi yang agak kompleks.

10) Visual yang dimaksudkan untuk mengkomunikasikan gagasan khusus atau efektif apabila:

(a) Jumlah objek dalam visual yang akan ditafsirkan dengan benar dijaga agar terbatas,

(b) Jumlah aksi terpisah yang penting yang pesan-pesannya harus ditafsirkan dengan benar sebaiknya terbatas, dan

(c) Semua objek dan aksi yang dimaksudkan dilukiskan secara realistik sehingga tidak terjadi penafsiran ganda.

11) Unsur-unsur pesan dalam visual itu harus ditonjolkan dan dengan mudah dibedakan dari unsur-unsur latar belakang untuk mempermudah penglahan informasi.

12) Caption (keterangan gambar) harus disiapkan terutama untuk:

(a) Menambah informasi yang sulit dilukiskan secara visual, seperti lumpur, kemiskinan, dan lain-lain,

(b) Memberi nama orang, tempat, atau objek,

(c) Menghubungkan kejadian atau aksi dalam lukisan dengan visual sebelum atau sesudahnya dan

(d) Menyatakan apa yang orang dalam gambar itu sedang kerjakan, pikirkan, atau katakana.

13) Warna harus digunakan secara realistic

14) Warna dan pemberian bayangan digunakan untuk mengarahkan perhatian dan membedakan komponen-komponen. ${ }^{15}$

\footnotetext{
${ }^{15}$ Azhar Arsyad, Media Pembelajaran, Edisi Revisi, Cetakan ke- 17, (Jakarta, Rajawali Pers, 2014) h. 89-90.
}

\section{E. Media Video}

Kemajuan teknologi di era sekarang ini berdampak pada banyak hal. Salah satu dampak kemajuan teknologi dapat kita rasakan pada dunia pendidikan. Banyak sekali muncul berbagai macam media pembelajaran baru yang kita gunakan untuk mengoptimalkan proses penyerapan materi dalam prose pembelajaran. Dalam penggunaan media pembelajaran kita perlu memilih yang cocok dan sesuai serta layak digunakan dalam proses belajar mengajar. Semua media pembelajaran dapat digunakan seperti media animasi, gambar, film-film, dan lain sebagainya. ${ }^{16}$

Menurut Azhar Arsyad, video merupakan sebuah gambar yang berada dalam frame, yang mana frame-frame tersebut akan diproyeksikan melalui lensa proyektor sehingga gambar tersebut terlihat seperti pada layar yang memancarkan gambar yang hidup. ${ }^{17}$ Secara umum video merupakan salah satu elemen penting yang ikut berperan dalam membangun sebuah sistem komunikasi dalam bentuk gambar bergerak. Video mrupakan salah satu media pembelajaran yang dapat digunaka dalam pembelajaran. Dan video merupakan salah satu jenis media pembelajaran yang tergolong audio visual. Media audio visual merupakan bentuk media pembelajaran yang murah dan terjangkau. Disamping menarik dan memotivasi siswa untuk mempelajari materi lebih banyak, materi audio dapat digunakan untuk keperluan berikut:

a. Mengembangkan keterampilan mendengar dan mengevaluasi apa yang telah didengar.

b. Mengatur dan mempersiapkan diskusi dengan mengungkapkan pendapat-

\footnotetext{
${ }^{16}$ Zulkifli, Media Pembelajaran, Bias Cemerlang Kota Tangerang 2018 h. 95.

${ }^{17}$ Azhar Arsyad, Media Pembelajaran, Edisi Revisi, Cetakan ke- 15, (Jakarta, Rajawali Pers, 2011) h. 49.
} 
pendapat para ahli yang berada jauh dari lokasi.

c. Menjadikan modle yang akan ditiru oleh siswa

d. Menyiapkan variasi yang menarik mengenai suatu pokok bahasan atau sesuatu masalah.

Umumnya program video telah dibuat dalam rancangan lengkap, sehingga setiap akhir penayangan, siswa dapat menguasi suatu atau lebih kompetensi dasar. ${ }^{18}$ Materi disajikan dengan mengikuti langkah-langkah menggunakan materi pembelajarn dalam bentuk lain. Langkahlangkah itu adalah sebagai berikut

a. Mempersiapkan diri. Guru merencanakan dan mempersiapkan diri sebelum penyajian materi.

b. Membangkitkan kesiapan siswa. Siswa dituntun agar memiliki kesiapan untuk memperhatikan, misalnya dengan cara memberikan komentar awal dan pertanyaan-pertanyaan.

c. Memperhatikan materi video. Tuntun siswa untuk menjalani pengalaman memperhatikan dengan video yang telah disiapkan dengan waktu yang tepat.

Berikut ini aplikasi video untuk domain pembelajaran kognitif, afektif, psikomotorik, dan interpersonal:

1) Ranah Kognitif. Para siswa bisa mengobservasi dari peristiwa masa lalu dan rekaman actual terkini. Selain itu dengan menggunakan mediaini bisa memperkuat pemahaman siswa terhadap suatu materi.

2) Ranah Afektif. Video dapat memperkuat siswa dalam merasakan unsur emosi dan penyikapan dari pembelajaran yang efektif. Sehingga dengan video ini mampu membuat siswa tertawa karena gembira,

${ }^{18}$ Zulkifli, Media Pembelajaran, Bias Cemerlang Kota Tangerang 2018 h. 96. menangis karena sedih, dan marah karena susasana yang mengagetkan.

3) Ranah Psikomotorik. Video memiliki keunggulan dalam memperlihatkan sesuatu itu bekerja. Misalnya video tentang tata cara berwudhu, dari video yang ditampilkan tersebut maka siswa bisa menirukan,

4) Ranah Kemampuan Interpersonal. Video memberikan kesempatan kepada siswa untuk mendiskusikan apa yang telah ditnton secara berjamaah. Dan mereka juga bisa saling mengobservasi dan menganalisis atas tayangan video tersebut. ${ }^{19}$

\section{F. Manfaat Multimedia}

Multimedia dalam pendidikan tentunya dikembangkan atau dibangun guna memperoleh manfaat yang sebesarbesarnya bagi institute pendidikan, khususnya bagi peserta didik maupun pengajar. Berikut ini deskripsi dari manfaat multimedia pembelajaran bagi peserta didik dan pengajar, antara lain:

a. Dapat belajar sesuai waktu dan kesempatan yang tersedia.

b. Dapat belajar di ruang kelas atau tempat yang berbeda.

c. Dapat belajar dengan tutor yang sabar (multimedia sebagai tutor).

d. Dapat belajar secara aktif dan menerima feedback.

e. Dapat meningkatkan aspek motivasi dalam belajar secara mandiri /kolaboratif.

Manfaat multimedia pembelajaran bagi pengajar/pendidik antara lain:

a. Menghemat waktu dengan topic yang lebih menntang.

b. Dapat mengevaluasikan konte32n dan materi yang abstrak, dinamis melalui proses.

\footnotetext{
${ }^{19}$ Sharon E. Smaldin, dkk. Intructional Technology and Media For Learning, (Jakarta: Kencan, 2012) h. 405
} 
c. Dapat menyimulasikan ekperimeneksperimen riil yang kompleks.

d. Dapat bekerja secara lebih kreatif.

e. Menggantikan aktivitas belajar yang tidak efektif.

f. Dapat menambah waktu kontak peserta didik untuk berdiskusi. ${ }^{20}$

Zulkifli mengemukakn kelebihan nultimedia adalah untuk menarik indera dan menarik minat, karena merupakan gabungan, suara dan gerakan. Lembaga riset dan penerbitan komputer, yaitu Computer Technology Research (CTR), menyatakan bahwa orang hanya mampu mengingat 20\% dari yang dilihat dan 30\% dari yang didengar. Tetapi orang dapat mengingat $50 \%$ dari yang dilihat dan di dengar dan $80 \%$ dari yang dilihat, didengar, dan dilakukan sekaligus. ${ }^{21}$

a) Siswa dapat belajar sesuai dengan kemampuan, kesiapan dan keinginan mereka. Artinya pengguna sendirilah yang mengontrol proses pembelajaran.

b) Siswa akan terdorong untuk mengejar pengetahuan dan memperoleh umpan balik seketika.

c) Siswa dapat menghadapi suatu evaluasi yang obyektif melalui keikutsertaanya dalam latihan atau tes yang disediakan.

d) Belajar kapan saja mereka mau tanpa terikat suatu waktu yang telah ditentukan.

e) Memberikan fasilitas bagi siswa.

Penggunaan perangkat lunak multimedia dalam proses belajar mengajar akan meningkatkan efisiensi, motivasi, memfasilitasi belajar aktif dan eksperimental konsisten dengan belajar yang berpusat pada siswa, dan membantu

\footnotetext{
${ }^{20}$ Muhammad Rusli, Dadang Hermawan, dan Ni Nyoman Supuwaningsih, Multimedia Pembelajaran yang Inovatif, CV Andi Offset Jl. Beo 38-40, Yogyakarta 2017 h. 4

${ }^{21}$ Zulkifli, Media Pembelajaran, Bias Cemerlang Kota Tangerang 2018 h. 110.
}

untuk lebih baik. $^{22}$ Multimedia juga digunakan pada proses belajar mengajar jarak jauh (distance learning). Beberapa perguruan tinggi telah menerapkan pendidikan jarak jauh dengan menggunakan multimedia online. Pemanfaatan multimedia juga dimanfaatkan dalam bidang pemasaran perguruan tinggi yang menjadikan perguruan tinggi atau sekolah tersebut dapat meningkatkan keunggulan bersaingnya.

Multimedia berbasis komputer ini sangat menjanjikanuntuk penggunaanya dalam bidang pendidikan. Meskipun saat ini penggunaan media masih dianggap mahal, dalam beberapa tahun mendatang biaya itu akan semakin rendah dan dapat terjangkau sehingga dapat digunakan secara meluas diberbagai jenjang sekolah.

\section{B. Motivasi Belajar}

1. Definisi Motivasi Belajar

Banyak sekali, bahkan sudah umum orang menyebut dengan "motif" untuk menunjuk mengapa seseorang itu berbuat sesuatu. Apa motfinya si Badu itu membuat kekacauan, apa motfinya si Aman itu rajin membaca, apa motifnya Pak Jalu Memberikan inseitif kepada para pembantunya, dan begitu seterusnya. Kalau demikian, apa yang dimaksud dengan motif.? Kata "motif", diartikan sebagai daya upaya yang mendorong seseorang untuk melakukan sesuatu. Mtif dapat dikatakan sebagai daya penggerak dari dalam dan di dalam subje untuk melakukan aktivitas-aktivitas tertentu demi mencapai suatu tujuan. Bahkan motif dapat diartikan sebagai suatu kondisi intern (kesiapsiagaan). Berawal dari kata "motif" itu, maka motivasi dapat diartikan sebagai daya penggerak yang telah menjadi aktif.

\footnotetext{
${ }^{22}$ Suryanto, M. Multimedia Alat Untuk Meningkatkan Keunggulan Bersaing. 2005. Yogyakarta: C.V Andi Offset h. 23
} 
Mtif menjadi aktif pada saat-saat tertentu, terutama bila kebutuhan untuk mencapai tujuan sangat dirasakan mendesak. ${ }^{23}$

Motivasi akan menyebabkan terjadinya suatu perubahan energy yang ada pada diri manusia, sehingga akan bergayut dengan persoalan gejala kejiwaan, perasaan dan juga emosi, untuk kemudian bertindak atau melakukan sesuatu. Semua ini didorong karena adanya tujuan, kebutuhan atau keinginan. ${ }^{24}$

Selain itu, motivasi dapat dikatakan sebagai dorongan psikologis pada seseorang sehingga melakukan tindakan untuk mencapai tujuan tertentu baik secara sadar maupun tidak sadar. ${ }^{25}$ Hal ini didukung oleh syaiful, yang menguatkan bahwa motivasi adalah gejala psikologis dalam bentuk dorongan yang timbul pada diri seseorang sadar atau tidak sadar untuk melakukan suatu tindakan dengan tujuan tertentu. $^{26}$

Dalam kegiatan belajar, motivasi dapat dikatakan sebagai keseluruhan daya penggerak di dalam diri siswa yang menimbulkan kegiatan belajar, yang menjamin kelangsungan dari kegiatan belajar dan yang memberikan arah pada kegiatan belajar, sehingga tujuan yang dikehendaki oleh subjek belajar itu dapat tercapai. Dikatakan "keseluruhan", karena pada umumnya ada beberapa motif yang

${ }^{23}$ Sardiman, Interaksi dan Motivasi Belajar Mengajar. Ed.1, cet. 24. Depok: Rajawali Pers, 2018 h. 73.

${ }^{24}$ Sardiman, Interaksi dan Motivasi Belajar Mengajar. Ed.1, cet. 2 4. Depok: Rajawali Pers, 2018 h. 74

${ }^{25}$ Achmad Badaruddin, Peningkatan Motivasi Belajar Siswa melalui Konseling Klasikal, Abe Kreatifindo Padang Sumatera Barat 2015 h. 13.

$$
{ }^{26} \text { Ibid h. } 13 .
$$

bersama-sama menggerakan siswa untuk belajar. $^{27}$

Motivasi memiliki peranan yang cukup besar dalam upaya belajar. Tanpa motivasi hampir tidak mungkin siswa melakukan kegiatan belajar. Motivasi merupakan salah satu faktor yang turut menentukan kefektifan belajar karena motivasi menyebabkan adanya tingkah laku kearah tujuan tertentu. Oleh karena itu, motivasi merupakan suatu bagian yang sangat penting dan harus di perhatikan dalam pembelajaran. Para peserta didik akan belajar dengan sungguh-sungguh apabila memiliki motivasi yang tinggi dan mereka akan memperlihatkan minat, mempunyai perhatian, dan ingin terlihat dalam suatu tugas atau kegiatan. Dengan kata lain, peserta didik akan melakukan semua tugas belajarnya dengan baik apabila ada faktor pendorong (motivasi/nafsu). ${ }^{28}$

Motivasi belajar adalah dorongan psikologis seseorang yang melakukan suatu tindakan untuk mencapai tujuan belajar. Hal ini diperkuat oleh hakikat motivasi belajar, bahwa hakikat motivasi belajar adalah dorongan internal dan eksternal pada siswa-siswa yang sedang belajar untuk mengadakan perubahan tingkah laku, pada umumnya dengan beberapa indikator atau unsur yang mendukung. Hal itu yang memiliki peranan besar dalam kesuksean mencapai tujuan belajar. ${ }^{29}$

${ }^{27}$ Sardiman, Interaksi dan Motivasi Belajar Mengajar. Ed.1, cet. 24. Depok: Rajawali Pers, 2018 h. 75.

${ }^{28}$ Totong Heri, "Meningkatkan Motivasi Minat Belajar Siswa" Rausyan Fikr Jurnal Pemikiran \& Pencerahan Agama Islam Universitas Muhammadiyah Tangerang, No.1, Volume 15, Maret 2019 h. 61

${ }^{29}$ Achmad Badaruddin, Peningkatan Motivasi Belajar Siswa melalui Konseling Klasikal, Abe Kreatifindo Padang Sumatera Barat 2015 h. 18 


\section{Fungsi Motivasi Belajar}

Serangkaian kegiatan yang dilakukan oleh seseorang itu sebenarnya diltarbelakangi oleh sesuatu atau yang secara umum dinamakan motivasi. Motivasi inilah yang mendorong mereka untuk melakukan suatu kegiatan/pekerjaan. Begitu juga untuk belajar sangat diperlukan adanya motivasi. Motivation is an essential condition of learning. Hasil belajar akan menjadi optimal, kalau ada motivasi. Makin tepat motivasi yang diberikan, akan makin berhasil pula pelajaran itu. Jadi motivasi akan senantiasa menentukan intensitas usaha belajar bagi para siswa. ${ }^{30}$ Dengan demikian, motivasi memengaruhi adanya kegiatan. Sehubungan dengan hal tersebut ada tiga fungsi motivasi:

1) Mendoong manusia untuk berbuat, jadi sebagai penggerak atau motor yang melepaskan energi. Motivasi dalam hal ini merupakan motor penggerak dari setiap kegiatan yang akan dikerjakan.

2) Menentukan arah perbuatan, yakni kea rah tujuan yang hendak dicapai. Dengan demikian motivasi dapat memberikan arah dan kegiatan yang harus dikerjakan sesuai dengan rumusan tujuannya.

3) Menyeleksi perbuatan, yakni menentukan perbuatan-perbuatanapa yang harus dikerjakan yang serasi guna mencapai tujuan, dengan menyisihkan perbuatan-perbuatan yang tidak bermanfaat bagi tujuan tersebut. Seseorang siswa yang akan menghadapi ujian dengan harapan dapat lulus, tentu akan melakukan kegiatan belajar dan tidak akan menghabiskan waktunya untuk

\footnotetext{
${ }^{30}$ Sardiman, Interaksi dan Motivasi Belajar Mengajar. Ed.1, cet. 24. Depok: Rajawali Pers, 2018 h. 84.
}

bermain kartu atau membaca komik, sebab tidak serasi dengan tujuan. ${ }^{31}$

Motivasi berfungsi sebagai pendorong usaha dan penapaian prestasi. Adanya motuvasi yang baik dalam belajar akan menunjukan hasil yang baik. Demikian pula apabila seorang mengetahui bahwa rangkaian dari niat belajar yang baik, dilakukan dengan baik pula maka ia akan memberi alternative yang tepat apabila dibalik, bahwa prestasi adalah menjadi motivasi belajar bagi anak. Bila ini terjadi maka motivasi akan memberikan kepuasan sesaat dan bukan permanen sebagaimana yang diinginkan dalam hukum belajar. ${ }^{32}$

\section{B. Faktor-Faktor Yang Mempengaruhi Motivasi Belajar \\ Dalam kegiatan belajar mengajar} peranan motivasi sangat diperlukan. Motivasi bagi siswa dapat mengembangkan aktifitas dan insiatif, dapat mengarahkan akan memlihara ketekunan dalam melakukan kegiatn belajar. Dalam kaitannya dengan itu diketahui ada beberapa faktor yang dapat mempengaruhi motivasi belajar, yaitu: ${ }^{33}$

1. Kematangan. Dalam pemberian motivasi, faktor kematangan fisik, social dan psikis haruslah diperhatikan, karena hal ini dapat mempengaruhi motivasi. Seandainya dalam pemberian motivasi itu tidak memperhatikan kematangan, maka akan mengaikbatkan frustasi dan

\footnotetext{
${ }^{31}$ Sardiman, Interaksi dan Motivasi Belajar Mengajar. Ed.1, cet. 24. Depok: Rajawali Pers, 2018 h. 85.

${ }^{32}$ Kompri, Motivasi Pembelajaran Perspektif Guru Dan Siswa, Bandung: PT Remaja Rosdakarya. 2018 h. 237.

${ }^{33}$ Agustina, Arni Penerapan Metode Ice Breaker Dalam Meningkatkan Motivasi Belajar Siswa Kelas Vii Pada Mata Pelajaran Pai Di SMP PGRI Betung.( (Skripsi) S1 Program Studi Islam UIN Raden Fatah, Palembang, 2016)h. 57
} 
mengakibatkan hasil belajar tidak optimal.

2. Usaha yang bertujuan. Setiap usaha yang dilakukan mempunyai tujuan yang ingin dicapai. Semakin jekas tujuan yang ingin diacapai, akan semakin kuat dorongan untuk belajar.

3. Pengetahuan mengenai hasil dalam motivasi. Dengan mengetahui hasil belajar, siswa terdorong untuk lebih giat belajar. Apabila hasil belajar itu mengalami kemajuan, siswa akan berusaha untuk mempertahankan atau meningkat intensitas belajarnya untuk mendapatkan prestasi yang lebih baik di kemudian hari. Prestasi yang rendah menjadikan siswa giat belajar guna memperbaikinya.

4. Partisipasi. Dalam kegiatan mengajar perlu diberikan kesempatan pada siswa untuk berpartisipasi dlam seluruh kegiatan belajar. Dengan demikian kebutuhan siswa akan kasih saying dan kebersamaan dapat diketahui, karena siswa merasa dibutuhkan dalam kegiatan belajar itu.

5. Penghargaan dan hukuman. Pemberian penghargaan dan hukuman itu dapat membangkitkan siswa untuk mempelajari atau mengerjakan sesuatu. Tujuan pemberian penghargaan berperan untuk membuat pendahuluan saja. Penghargaan adalah alat, bukan tujuan. Hendaknya diperhatikan agar penghargaan ini menjadi tujuan. Tujuan pemberian penghargaan dalam belajar adalah bahwa setelah seseorang menerima penghargaan karena telah melakukan kegiatan belajar yang baik, ia akan melanjutkan kegiatan belajarnya sendiri di luar kelas. Sedangkan hukuman sebagai reinforcement yang negative tetapi kalau diberikan secara tepat dan bijak bisa menjadi alat motivasi.
C. Indikator Motivasi Belajar Siswa

Motivasi yang bekerja dalam diri individu mempunyai kekuatan yang berbeda-beda. Ada motif yang begitu kuat sehingga menguasai motif-motif lainnya. Motif yang paling kuat adalah motif yang menjadi sebab utama tingkah laku individu pada saat tertentu. Motif yang lemah hampir tidak mempunyai pengaruh pada tingkah laku individu. Motif yang kuat pada suatu saat akan menjadi sangat lemah karena ada motif lain yang lebih kuat pada saat itu.

Menurut Martin Handoko yang dikutip oleh Sadirman dalam bukunya menyatakan bahwa untuk mengetahui kekuatan motivasi belajar siswa, dapat dilihat dari beberapa indikator sebagai berikut:

1. Kuatnya kemauan untuk berbuat

2. Jumlah waktu yang disediakan untuk belajar

3. Kerelaan meninggalkan kewajiban atau tugas yang lain

4. Ketekunan dalam mengerjakan tugas.

Sedangkan menurut indikator motivasi belajar adalah sebagai berikut:

1. Tekun menghadapi tugas.

2. Ulet menghadapi kesulitan (tidak lekas putus asa)

3. Menunjukkan minat terhadap bermacam-macam masalah orang dewasa.

4. Lebih senang bekerja mandiri.

5. Cepat bosan pada tugas- tugas rutin

6. Dapat mempertahankan pendapatnya. Apabila seseorang memiliki ciri-ciri di atas berarti seseorang itu memiliki motivasi yang tinggi. Ciri-ciri motivasi seperti itu akan sangat penting dalam kegiatan belajar. Kegiatan belajar akan berhasil baik kalau siswa tekun mngerjakan tugas, ulet dalam memecahkan berbagai masalah dan hambatan secara mandiri, siswa yang 
belajar dengan baik tidak akan terjebak pada sesuatu yang rutinitas. ${ }^{34}$

\section{Metodologi Penelitian}

Jenis penelitian ini adalah penelitian kualitatif deskriptif, yaitu data yang dikumpulkan berbentuk kata-kata, gambar, bukan angka-angka. ${ }^{35}$ Menurut Bogdan dan Taylor, sebagaimana yang dikutip oleh Lexy J. Moleong, penelitian kualitatif adalah prosedur penelitian yang menghasilkan data deskriptif berupa katakata tertulis atau lisan dari orang-orang dan perilaku yang diamati. ${ }^{36}$

Sementara itu, penelitian deskriptif adalah suatu bentuk penelitian yang ditujukan untuk mendeskripsikan atau menggambarkan fenomena-fenomena yang ada, baik fenomena alamiah maupun rekayasa manusia. ${ }^{37}$ Adapun tujuan dari penelitian deskriptif adalah untuk membuat pencandraan secara sistematis, faktual, dan akurat mengenai fakta dan sifat populasi atau daerah tertentu. Penelitian ini digunakan untuk mengetahui bagaimana upaya penggunaan perangkat multimedia untuk meningkatkan motivasi belajar siswa kelas VIII di Madrasah Tsanawiyah AlMu' in Kota Tangerang.

Pendekatan dalam Penelitian ini menggunakan analisis diskriptif kualitatif. Adapun teknik pengumpulan data, selain studi pustaka, observasi, diskusi, dan juga menggunakan analisis data melalui

60.

${ }^{34}$ Agustina, Arni Penerapan Metode.h. 58-

${ }^{35}$ Sudarwan Danim, Menjadi Peneliti Kualitatif Rancangan Metodologi, Presentasi, dan Publikasi Hasil Penelitian untuk Mahasiswa dan Penelitian Pemula Bidang Ilmu Sosial, Pendidikan, dan Humaniora, (Bandung: Remaja Rosdakarya, 2002), Cet. I, h. 51

${ }^{36}$ Lexy. J. Moleong, Metodologi Penelitian Kualitatif Edisi Revisi, (Bandung: PT Remaja Rosdakarya, 2017), h. 3

${ }^{37}$ Lexy. J. Moleong, Metodologi Penelitian Kualitatif, h. 17 penelaahan yang dilakukan secara intensif, mendetail, dan komprehensif, yaitu dilakukan pencocokan atau kesesuaian perkembangan pendidikan di Indonesia.

\section{Hasil Penelitian Dan Pembahasan a. Analisis Data dan Hasil Penelitian} Setelah peneliti melakukan penelitian di MTs Al-Mu'in Kota Tangerang dengan metode observasi, wawancara, dan dokumentasi dapat di paparkan temuan penelitian sebagai berikut: Motivasi belajar adalah dorongan psikologis seseorang yang melakukan suatu tindakan untuk mencapai tujuan belajar. Hal ini diperkuat oleh hakikat motivasi belajar, bahwa hakikat motivasi belajar adalah dorongan internal dan eksternal pada siswa-siswa yang sedang belajar untuk mengadakan perubahan tingkah laku, pada umumnya dengan beberapa indikator atau unsur yang mendukung. Hal itu yang memiliki peranan besar dalam kesuksean mencapai tujuan belajar. Indikator motivasi belajar dapat diklasifikasikan sebagai berikut: adanya hasrat dan keinginan berhasil; adanya dorongan dan kebutuhan dalam belajar; adanya harapan dan cita-cita masa depan; adanya penghargaan dalam belajar; adanya kegiatan yang menarik dalam belajar; dan adanya lingkungan belajar yang kondusif, sehingga memungkinkan siswa dapat belajar dengan baik.

Untuk mengetahui seberapa jauh penggunaan perangkat multimedia untuk meningkatkan motivasi belajar siswa di MTs Al-Mu'in terhadap mata pelajaran SKI ini menyangkut beberapa faktor yaitu:

1. Penggunaan perangkat multimedia dalam meningkatkan motivasi belajar siswa pada mata pelajaran sejarah kebudayaan Islam

Untuk mengetahui bagaimana penggunaan perangkat multimedia dalam meningkatkan motivasi belajar siswa 
adalah dengan cara mengetahui metode apa yang digunakan oleh guru SKI dalam pembelajaran di kelas. Metode merupakan cara yang digunakan untuk mengimpelmentasikan rencana yang sudah disusun dalam kegiatan nyata (dalam proses pembelajaran) agar tujuan yang telah tersusun tercapai secara optimal. Sehingga guru harus dapat memilih dan memilah metode yang tepat dan sesuai. Selain itu juga, guru harus dapat memperhatikan keadaan dan kondisi siswa pada waktu belajar. Berdasarkan hasil wawancara dengan kepala Madrasah, Pak Sofwan, mengatakan: "Sekolah sudah menyiapkan kebutuhan-kebutuhan untuk melakukan pembelajaran menggunakan perangkat multimedia, meskipun masih dalam keterbatasan, diantara lain adalah:

1. Menggunakan proyektor sekolah sudah mempersiapkan meskipun masih belum terdapat di dalam setiap kelas.

2. Sekolah sudah mempunyai lab komputer sendiri untuk menunjang pembelajaran komputer

3. Wifi pun sudah tersedia disekolah untuk membantu siswa dalam belajar.

Akan tetapi ketika fasilitas semua sudah tersedia jika seorang pendidik tidak bisa menggunakan fasilitas tersebut untuk membantu pembelajaran berarti sulit utuk menjadi pendidik yang baik, guru-guru di MTs Al-Mu'in sudah dipersiapkan untuk pembelajaran-pembelajaran berbasis multimedia, contohnya seperti bulan lalu kami membuat workshop untuk kreatifitas pembelajaran menggunakan media video, jadi selama pandemi seperti sekarang ini yang mengharuskan semua pembelajran diganti dengan metode daring, kami tidak cemas dan kesulitan untuk melakukan pembelajaran daring" Berdasarkan hasil wawancara dengan pak Maman selaku guru SKI, mengatakan: "Metode yang sering saya gunakan dalam menyampaikan materi adalah:
1) Metode ceramah

2) Metode diskusi,

3) Media proyektor dengan menonton video yang berkaitan dengan materi.

Selama pandemi ini otomatis metode yang digunakan adalah dengan metode daring video, pendidik harus mempersiapkan dengan membuat video yang isinya adalah saya sedang menyampaikan materi untuk pembelajaran siswa, biasanya saya mempersiapkan semalam sebelum jadwal mengajar saya, kemudian keesokan harinya saya menshare video tersebut melalui grup whatsaap kelas dan memerintahkan siswa untuk menyimak dan mencatat isi yang ada di dalam video, terkadang juga saya memberikan mereka tugas untuk membuat video sendiri dengan mempraktekan menjelaskan materi yang ditentukan "Berdasarkan Wawancara saya dengan Siswa yang bernama Vivian, mengatakan: "Dalam menyampaikan materi bapak Maman biasanya menggunakan metode ceramah, kemudian membahas materi maupun soal yang ada di LKS, selain metode ceramah dan LKS beliau kadang menggunakan metode diskusi tapi sangat jarang sekali, kemudian menggunakan metode media visual dan video itu hanya sesekali, selama pandemi ini karena tidak bisa bertaap muka langsung beliau menggunakan media video "Sedangkan menurut Siswa yang bernama Lutfiah mengatakan: "Dalam menyampaikan materi beliau sering menggunkan metode ceramah, membahas LKS, meminta siswa secara acak untuk menyampaikan materi yang ada di LKS, kemudian beliau menjelaskan kembali materi tersebut, menggunakan media video juga pernah, tapi saya kurang semangat saat menggunakan media video atau media proyketor, alasanya karena lebih membosankan, siswa siswa yang lain jadi sibuk sendiri-sendiri, ada yang memperhatikan video itu sampai selesai, 
ada yang diam saja, ada yang bercanda, gurunya juga hanya diam saja tidak ada penjelasan ulang" Berdasarkan hasil wawancara diatas dapat diambil kesimpulan bahwasanya dalam menyampaikan materi guru SKI bapak Maman di MTs Al-Mu'in menggunakan metode ceramah, diskusi, dan media video.

Dari observasi peneliti pada saat proses menyampaikan materi Bapak Maman selama pandemi beliau menggunakan media video, beliau mempersiapkan materi untuk disampaikan melalui video, yaitu semalam sebelum jadwal mengajar beliau, sebelum masa pandemi proses pembelajaran beliau hanya menggunakan metode ceramah, pada saat itu, materi yang disampaikan oleh bapak Maman adalah tokoh-tokoh ilmuan Bani Abbasiyah. Dari awal pembelajaran siswa begitu kondusif, namun setelah sekitar 30 menit, siswa mulai gaduh, ada yang izin ke wc tidak balik balik, ada yang memperhatikan, ada yang bercanda. Ini bisa peneliti ambil kesimpulan bahwa siswa mulai bosan dengan cara Bapak Maman menyampaikan materi. Akan tetapi ketika saat siswa disuruh menjelaskan lewat LKS siswa yang lain mulai membuka-buka LKS mereka.

$$
\text { Jadi pengguaan perangkat }
$$

multimedia di MTs. Al-Mu' in ini belum begitu signifikan karena keterbatasan nya perangkat multimedia itu sendiri, namun guru-guru di MTs Al-Mu'in sudah menguasai untuk pembelajaran multimedia tersebut. Guru sebaiknya memahami dan mengetahui macam metode megajar SKI, agar dapat menyesuaikan dengan situasi yang dihadapi oleh siswa. Metode mengajar guru yang kurang baik akan mempengaruhi belajar siswa yang tidak baik pula. Metode mengajar yang kurang baik ini dapat terjadi misalnya, karena guru kurang pesiapan dan kurang menguasai bahan pelajaran, sehingga guru tersebut menyajikannya tidak jelas, atau sikap guru terhadap siswa dan atau terhadap mata pelajaran itu sendiri tidak baik, sehingga siswa kurang senang terhadap pelajaran atau gurunya. Akhirnya siswa malas untuk belajar. Sebagai guru SKI untuk menumbuhkan motivasi belajar siswa, guru harus mengetahui karakteristik siswa dan mengetahui macam-macam metode. Agar dalam menyampaikan materi dapat tersampaikan dengan baik dan siswa menjadi tidak bosan dalam mendengarkan penjelasan, serta siswa menjadi berminat untuk belajar SKI yang banyak pelajaran ini tidak disukai oleh para siswa.

2. Pemilihan Perangkat Multimedia dalam Meningkatkan Motivasi Belajar Siswa

Pada dasarnya fungsi media adalah menumbuhkan motivasi siswa, dapat mengingat pelajaran dengan mudah, siswa menjadi aktif dalam merespon, memberi umpan balik dengan cepat, mendorong siswa untuk melaksanakan kegiatan praktek dengan cepat.

Berdasarkan Wawancara dengan Bapak Kepala Madrasah, Bapak Sofwan mengatakn: "Fasilitas yang sudah sekolah berikan untuk menningkatkan motivasi belajar siswa, antar lain yaitu papan tulis, LCD proyektor, WIFI, Lab Komputer untuk mendukung pembelajaran komputer, walaupun LCD di sekolah kami masih terbatas, akan tetapi untuk masalah teknologi sekolah kami tetap berikan yang terbaik. Seperti yang tadi saya sampaikan di pertanyaan sebelumnya, termasuk guruguru di sini sudah saya siapkan sebaik mungkin untuk pembelajaran menggunakan media-media seperti proyektor, kemudian membuat video, jadi pas pandemi sekarang ketika pembelajaran seluruhnya dialihkan kepada daring, kita semua sudah siap untuk membuat metode daring lebih menyenangkan." Berdasarkan wawancara dengan bapak Maman, mengatakan bahwa: "Media yang saya 
gunakan pada proses pembelajaran biasanya menggunakan papan tulis dalam menyampaikan materi, tidak ketinggalan juga yaitu buku LKS. Dengan menggunakan LKS jadi siswa lebih mudah untuk mengingat bahwa saya pernah menjelaskan materi yang sampaikan dan bisa mereka pelajari dirumah, saya juga menggunakan media video dalam pembelajaran, tapi itu hanya selingan saja tidak hampir setiap pertemuan, selain video saya menngunakan media visual seperti gambar-gambar, bagan."Berdasarkan wawancara dengan siswa yang bernama Davi, mengatakan: "Bapak Maman biasanya dalam pembelajaran menggunakan media papan tulis, LKS, dan sesekali pernah menggunakan media proyektor, tetapi jarang sekali penggunaanya, mungkin karena belum tersedia didalam setiap kelas. Dengan menggunakan proyektor saya sedikit tidak bosan dalam pembelajaran SKI. Menggunakan media proyektor pembelajaran menurut saya sedikit tidak monoton, apalagi ketika pembelajaran menggunakan media video saya bisa lebih fokus saat pembelajaran" Berdasarkan wawancara dengan siswa yang bernama Nadzhifah, mengatakan: "Beliau selain menggunakan papan tulis juga menggunakan LKS, dan menggunakan media viideo dalam menyampaikan materi. Dengan menggunakan media video saya lebih semangat dalam belajar dibandingkan hanya menggunakan LKS, atau kita menulis ulang materi yang ada di papan tulis, sebenarnya pembelajaran SKI tidak membosankan melainkan menyenangkan. Dengan sejarah kita menjadi mengerti masa lampau." Dari hasil wawancara tersebut dapat diambil kesimpulan bahwa di dalam pengajaran bapak Maman memilih media LCD, media video, LKS dan papan tulis. Namun pemilihan multimedia (media video dan media visual) dalam pembelajaran hanya menjadi sebuah selingan saja tidak menjadi pilihan utama dalam metode pembelajaran di kelas. Guru harus pintar memilih media pembelajaran dalam penyampaian materi, agar siswa menjadi tidak bosan saat menyampaikan materi. Media sangat membantu dalam menyampaikan materi dan menumbuhkan minat belajar siswa, serta perhatian siswa kepada gruru.

Pada saat peneliti melakukan observasi (sebelum pandemi) guru SKI menggunakan media papan tulis, LCD, Video dalam meningkatkan motivasi belajar siswa. Saat peneliti mengikuti proses belajar mengajar siswa sangat kondusif ketika guru menyampaikan materi dibantu dengan LCD proyektor. Selain menggunakan power point, guru memberikan video saat menjelaska materi, sehingga siswa menjadi tidak jenuh dalam mengikuti proses pembelajaran SKI. Dari hasil wawancara dengan Bapak Kepala Madrasah dengan menyediakan LCD, papan tulis, globe, perpustakaan, dan lain sebagainya untuk melancarkan proses pembelajaran yang mana pada mata pelajaran tertentu ada yang membutuhkan fasilitias tersebut. Penggunaan media pembelajaran yang dipilih guru tentunya harus sesuai dengan materi yang akan disampaikan kepada siswa. Pemilihan media dipilih agar siswa berlatih untuk aktif dan terbiasa percaya diri dalam mengeluarkan pendapat.

3. Sejauh manakah efektifitas pembelajaran menggunakan perangkat multimedia "Media Visual dan Media Video" terhadap motivasi belajar siswa

Multimedia merupakan salah satu teknologi pendidikan yang dapat menghadirkan visualisasi dari materi pelajaran, Dengan demikian, maka pembelajaran yang menggunakan multimedia akan sangat membantu, tidak hanya guru dalam menyampaikan materi 
tetapi juga siswa sebagai subjek pembelajaran, sehingga tujuan pembelajaran dapat tercapai secara maksimal. Penggunaan multimedia memberikan peranan yang penting dalam hal menimbulkan rasa senang kepada siswa selama proses pembelajaran berlangsung. Hal ini berarti bahwa media pembelajaran tersebut mampu menumbuhkan motivasi pada diri siswa, sehingga tujuan pembelajaran dapat tercapai dengan maksimal. Berdasarkan hasil wawancara dengan Kepala Madrasah, Bapak Sofwan mengatakan:"Pembelajaran mennggunakan multimedia sudah pasti akan lebih memotivasi anak dalam belajar, anak akan menjadi lebih mudah dalam memahami materi yang disampaikan, sejauh ini memang penggunaan perangkat multimedia di MTs Al-Mu'in masih terbatas, tetapi kami tetap memberikan pembelajaran yang terbaik agar para siswa tetap memiliki motivasi yang tiinggi dalam belajar" Hal yang serupa juga dikatakan oleh guru mata pelajaran SKI, Pak Maman: "Penggunaan perangkat multimedia pilihan yang paling utama untuk meningkatkan motivasi belajar siswa, dengan pembelajaran menggunakan perangkat multimedia akan membuat siswa menjadi lebih aktif di dalam kelas, kemudian akan memberikan pengalaman belajar yang menyenangkan bagi siswa, sejauh ini saya menggunakan perangkat multimedia itu hanya untuk selingan saja, dalam satu bulan itu hanya satu kali menggunakan media video, tapi ketika saya menggunakan multimedia dalam pembelajaran dikelas, terbukti siswa begitu antusias dalam memperhatikan materi yang disampaikan" Peneliti juga mewawancara murid yang bernama Vivian: "Saat pembelajaran menggunakan multimedia (media video dan visual) saya sangat antusias dalam menyimak pembelajaran yang disampaikan, namun jarang sekali pak Maman menggunakan multimedia dalam pembelajaran, ketika bulan lalu kaka dan teman-teman kaka PPL disini kami begitu antusias dalam menerima materi, karena tidak hanya metode ceramah yang diterapkan, melainkan beragam metode yang diterapkan, penggunaan perangkat multimedia hal yang paling ditunggu tunggu ketika kaka kaka mahasiswa mengajar ke kelas kami, itu membuat saya merasa lebih semangat untuk belajar, karena dengan melihat video saya lebih gampang untuk memahami mata peljaran SKI" Peneliti juga mewawancarai siswa yang bernama Davi: "Dalam pembelajaran menggunakan media video saya merasa lebih semangat untuk belajar, saya bisa lebih fokus dalam memahami materi, kalau bisa sih saya ingin belajar pakai media video terus, dengan belajar menggunakan video saya lebih termotivasi" Berdasarkan hasil wawancara di atas dapat disiimpulkan bahwasanya, sejauh ini pembelajaran menggunakan multimedia (video dan visual), sangat membantu siswa dalam meningkatkan motivasi belajar, namun karena keterbatsannya perangkat multimedia itu sendiri di sekolah membuat pembelajaran menggunakan perangkat multimedia itu tidak begitu signifikan, namun keterbatasan perangkat multimedia bukan alasan guru untuk tidak memberikan pembelajaran yang terbaik, dan juga jangan dijadikan alasan siswa untuk tidak semangat atau tidak termotivasi dalam pembelajaran.

\section{b. Pembahasan}

1. Penggunaan perangkat multimedia dalam meningkatkan motivasi belajar siswa pada mata pelajaran sejarah kebudayaan Islam

Pada hakikatnya perangkat multimedia adalah sebuah alat bantu untuk para guru dalam menjalankan tugasnya sebagai pendidik, penggunaan perangkat 
multimedia sudah sangat lazim digunakan didalam pembelajaran di padukan dengan metode metode pembelajaran untuk membantu meningkatkan motivasi siswa dalam belajar. Metode merupakan cara yang digunakan untuk meingmplementasikan rencana pembelajaran tercapai secara optimal. Guru seyogyanya memahami dan mengetahui berbagai macam metode mengajar, agar dapat menyesuaikan metode yang dipilihnya. Guru diharapkan mampu memilih dan menggunakan metode pembelajaran sesuai dengan materi yang akan disampaikan.

Pada saat peneliti melakukan observasi, guru dalam menyampaikan materi menggunakan metode sesuai dengan materi yang aka disampaikan. Misalnya, saat itu peneliti mengikuti proses pembelajaran dengan materi tokoh tokoh ilmuan Banni Abbasiyah guru menyampaikan materi dengan ceramah. Setelah beberapa menit dengan ceramah, guru menggunakan metode Tanya jawab dan memberikan kesempatan kepada siswa untuk menjelaskan sedikit materi yang disampaikan oleh guru. Hal ini, menunjukan keaktifn siswa dalam pembelajaran. Selain menggunakan metode Tanya jawab guru menggunakan metode kelompok. Jadi siswa disuruh untuk mengerjakan tugas dan setelah itu setiap anggota kelompok memberikan penjelasan tentang tugas yang diberikan kepada siswa tersebut.

Selain menggunakan metode diskusi pada saat peneliti melakukan observasi, saat itu guru juga menggunakan mtode media visual yaitu menunjukan gambar gambar para tokoh ilmuan hebat masa dinasti Abbasiyah. Sebagaimana teori yang di kemukakan oleh Syafruddin Nurdin: "Dalam penggunaan suaru metode mengajar disamping dilatar belakangi oleh beberapa faktor. Di persyaratkan pula kepada setiap pengguna dalam hal ini guru mengetahui dan menguasai metode yang akan digunakannya. Sebagai indikator apakah seorang guru tersebut mengetahui dan menguasai metode yang dipilihnya untuk menyampaikan materi pembelajaran, maka ia akan melaksanakan metode mengajar tersebut dengan langkah-langkah yang benar menurut teori penggunaanya." 38

Hal ini dapat peneliti simpulkan dalam meningkatkan motivasi belajar siswa MTs. Al-Mu'in Kota Tangerang pada mata pelajaran SKI pemilihan metode harus sesuai dengan materi yang disampaikan. Guru menggunakan metode untuk meningkatkn motivasi belajar yaitu dengan metode, tanya jawab, diskusi, dan media visual. Saat guru melkukan metode diskusi siswa sangat kondusif mengikutinya. Meskipun ada beberapa siswa yang masih belum jelas tentang materi yang disampaikan. Setidaknya sisw menjadi termotivasi dalam mengikuti pembelajaran, dengan siswa mulai mengikuti proses pembeljaran secara perlahan siswa akan menyukai pelajaran SKI.

Penggunaan perangkat multimedia di MTs. Al-Mu'in belum menjadi metode pilihan yang paling sering digunakan dalam pembelajaran, karena keterbatasan nya perangkat itu sendiri membuat pengaplikasiannya dalam metode pembelajaran belum menjadi pilihan utama guru untuk meningkatkan motivasi belajar siswa, maka dari itu guru harus mengetahui macam dan karakteristik metode, agar guru bisa menyampaikan materi dengan berbagai macam teri. Dengan mengetahui macam-macam metode, siswa tidak akan jenuh apabila metode yang digunakan sesuai dengan keadaan siswa tersebut. Waktu guru mengajar bila hanya

\footnotetext{
${ }^{38}$ Syafrudin Nurdin, Menjadi Guru Profesional,h. 95.
} 
menggunakan salah satu metode maka akan membosankan, siswa tidak tertarik perhatiannya pada pelajaran. Dengan variasi metode dapat meningkatkan motivasi belajar siswa.

Awal mula tentang penggunaan multimedia atau teknologi dalam komunikasi ataupun metode, termasuk komunikasi atau metode dalam pembelajaran. Hal ini diungkapkan dalam QS. An-Naml[27]; 29-30. Yaitu tentang cerita Nabi Sulaiman dan Ratu Balkis; “(28) Pergilah dengan (membawa) suratku ini, lalu jatuhkan kepada mereka, kemudian berpalinglah dari mereka, lalu perhatikanlah apa yang mereka bicarakan".(29) berkata ia (Balqis): "Hai pembesar pembesar, Sesungguhnya telah dijatuhkan kepadaku sebuah surat yang mulia, (30) Sesungguhnya surat itu, dari Sulaiman dan Sesungguhnya (isi)-nya: "Dengan menyebut nama Allah yang Maha Pemurah lagi Maha Penyayang.

Tafsir Jalalain membahas bahwa: "Pergilah membawa surahku ini, lalu jatuhkan kepada mereka) kepada ratu Balqis dan kaumnya (kemudian berpalinglah) pergilah (dari mereka) dengan tidak terlalu jauh dari mereka (lalu perhatikanlah apa yang mereka bicarakan" sebagai jawaban atau reaksi apakah yang bakal mereka lakukan. Kemudian burung hudhud membawa surat itu lalu mendatangi Ratu Balqis yang pada waktu itu berada di tengah-tengah bala tentaranya. Kemudian burung hud-hud menjatuhkan surat Nabi Sulaiman itu ke pangkuannya. Ketika Ratu Balqis membaca surat tersebut, tubuhnya gemetar dan lemas karena takut, kemudian ia memikirkan isi surat tersebut. Selanjutnya (Ia berkata) yakni ratu Balqis kepada pemuka kaumnya, (Hai pembesarpembesar! Sesungguhnya aku) dapat dibaca al-malā'u inn̄̄ dan almalā'u winni, yakni bacaan secara taḥqīq dan tashīl (telah dijatuhkan kepadaku sebuah surah yang mulia) yakni surat yang berstempel. (Sesungguhnya surat itu dari Sulaiman dan sesungguhnya isinya) kandungan isi surat itu, (Dengan menyebut nama Allah Yang Maha Pemurah lagi Maha Penyayang) Uraian tentang potongan cerita Nabi Sulaiman dan Ratu Balqis tersebut terjadi sebagai teknologi komunikasi yang canggih pada masa itu. Nabi Sulaiman menggunakan burung hudhud untuk menyampaikan pesan dalam bentuk surat yang disampaikan kepada Ratu Balqis, sehingga yang disampaikan dapat terima dengan baik sampai pada tujuan yang dikehendaki. Bahkan Nabi Sulaiman telah memperlihatkan teknologi yang canggih di istananya. ${ }^{39}$

Dalam melaksanakan proses pembelajaran, keaktifan siswa harus selalu di ciptakan dan berjalan terus dengan dengan menggunakan metode dan strategi mengajar yang tepat. Guru harus menciptakan suasana yang dapat mendorong siswa untuk bertanya, mengamati, mengadakan eksperimen, serta menemukan fakta dan konsep yang benar. Karena itu guru harus melakukan kegiatan pembelajaran menggunakan metode, sehingga terjadi suasana belajar sambil mendengar, bermain sesuai ruang lingkup materinya.

2. Pemilihan Perangkat Multimedia

Penggunaan multimedia merupakan cara untuk memotivasi, menumbuhkan minat dan komunikasi dengan siswa agar lebih efektif. Menggunakan multimedia dalam pembelajaran memungkinkan belajar secara individual dan personal sesuai dengan kecepatannya. Guru harus memiliki kemampuan dasar dalam

\footnotetext{
${ }^{39}$ Pusdiklat Tenaga Teknis Pendidikan dan Keagamaan, Abdul Haris Pito, Media Pembelajaran Dalam Perspektif Al-Qur'an, Volume: VI No. 2. Juli - Desember 2018 h. 112-113
} 
ketrampilan memilih media untuk meningkatkan minat belajar siswa.

Saat peneliti melakukan observasi media yang digunakan guru MTs. AlMu'in Poris Kota Tangerang adalah menggunakan media papan tulis fasilitas yang ada disetiap kelas. Dengan menggunakan media papan tulis guru menuliskan materi yang disampaikan saat itu, dengan menggunakan papan tulis memberikan ingatan yang kuat kepada siswa. Selain menggunakan media papan tulis guru juga menggunakan media video dan visual. Dengan menggunakan media video dan media visual guru berharap kepada siswa lebih memperhatikan guru dalam menyampaikan matei, meskipun penggunaan media video dan visual itu hanya sebatas selingan. Sebagaimana Teori yang dikemukakakan oleh Syafrudin Nurdin: "Setiap media pengajaran mempunyai karakteristik tertentu, baik dilihat dari segi keampuhannya, cara pembuatannya, maupun cara penggunaanya. Memahami karakteristik berbagai media pengajaran merupakan kemampuan dasar yang harus dimilki oleh guru dalam kaitannya dengan ketrampilan pemilihan media pengajaran. Disamping itu memberikan kemungkinan pada guru untuk menggunakan berbagai jenis media pengajaran secara bervariasi. Sedangkan apabila kurang memahami karakteristik media tersebut, guru akan dhadapkan kepada kesulitan dan cenderung bersifat spekulatif." Pada pembelajaran di sekolah, seorang guru dapat menciptakan suasana belajar yang menarik dengan memanfaatkan media pembelajaran yang kreatif, sehingga pembelajaran dapat berlangsung dengan mengoptimalkan proses dan berorientasi pada prestasi belajar. Dasar penggunaan media pembelajaran dalam proses belajar mengajar juga dapat ditemukan dalam QS. An-Nahl [16]:44. yaitu:"Kami Turunkan kepadamu Al-Qur'an, agar kamu Menerangkan pada umat manusia apa yang telah diturunkan kepada mereka dan supaya mereka memikirkan"

Demikan pula dalam masalah penerapan media pembelajaran, pendidik harus memerhatikan perkembanagan jiwa keagamaan anak didik, karena faktor inilah yang justru menjadi sasaran media pembelajaran. Tanpa memerhatikan serta memahami perkembangan jiwa anak atau tingkat daya pikir anak didik, guur akan sulit diharapkan untuk dapat mencapai sukses. Dapat peneliti simpulkan pemilihan multimedia untuk meningkatkan motivasi belajar siswa adalah dengan media proyektor, media video dan media visual, yaitu guru mengikuti perkembangan zaman meskipun masih dalam keterbatasan perangkat multimedia itu sendiri. Dan guru mencoba meningkatkan.

3. Sejauh manakah efektifitas pembelajaran menggunakan perangkat multimedia "Media Visual dan Media Video" terhadap motivasi belajar siswa.

Efektifitas pembelajaran dapat terlihat pada peserta didik yang tampak senang, tertarik dan sangat antusias mengikuti pembelajaran saat multimedia mulai di operasikan. Bahkan sebagian peserta didik menunjukan bahwa pembelajaran menggunakan multimedia mampu menumbuhkan motivasi belajar dan perhatian mereka dapat lebih difokuskan hasil penggunaan perangkat multimedia secara fokus dapat dirasakan guru dan peserta didik. Bagi guru, multimedia dalam pembelajaran dapat memudahkan penyampaian materi pelajaran sehingga menunjang dalam ketercapaian kompetensi yang diharapkan. Bagi peserta didik, multimedia dalam pembelajaran dapat meningkatkan perhatian sehingga memudahkan dalam memahami materi pelajara, dengan 
demikian penggunaan multimedia dalam pembelajaran menjadi sangat penting.

Teori diatas sudah sesuai dengan yang dihadapi siswa MTs Al-Mu'in Kota Tangerang, pada saat pembelajaran yang secara ringkas adalah pembelajaran menjadi lebih menarik sehingga meningkatkan motivasi belajar dan perhatian peserta didik. Meningkatkan daya ingat sehingga memudahkan pemahaman peserta didik terhadap materi yang disampaikan dan juga meningkatkan mutu pembelajaran karena multimedia pembelajaran dapat memperjelas penyajian materi dan mengatasi keterbatasan indera, ruang, dan waktu. Meskipunn penggunaan perangkat multimedia di MTs Al-Mu'in hanya sebagai selingan, tidak diterapkan dengan intens disetiap pembelajaran, akan tetapi sejauh ini penggunaan perangkat multimedia sangat membantu untuk meningkatkan keberhasilan motivasi belajar siswa dalam pembelajaran.

\section{Kesimpulan}

Berdasarkan hasil penelitian dengan menggunakan teknik wawancara, observasi, dan dokumentasi yang dilaksanakan di MTs Al-Mu' in Kota Tangerang tentang upaya penggunaan perangkat multimedia untuk meningkatkan motivasi belajar siswa pada mata pelajaran sejarah kebudayaan islam kelas VIII dapat diambil beberapa kesimpulan. Kesimpulan tersebut dipaparkan sebagai berikut:

1. Penggunaan perangkat multimedia dalam meningkatkan motivasi belajar siswa pada mata pelajaran sejarah kebudayaan Islam adalah Dengan cara guru mengunakan dan memadukan metode ceramah, diskusi, dan penggunaan perangkat multimedia seperti media video dan media visual.

2. Pemilihan media yang digunakan guru SKI adalah media papan tulis, media video, dan media visual. Namun fasilitas yang sudah ada disetiap kelas hanya media papan tulis.

3. Keefektifitasan pembelajaran dapat terlihat pada siswa yang tampak senang, tertarik dan sangat antusias mengikuti pembelajaran saat multimedia mulai di operasikan.

\section{DAFTAR PUSTAKA}

Arni, Agustina, "Penerapan Metode Ice Breaker Dalam Meningkatkan Motivasi Belajar Siswa Kelas Vii Pada Mata Pelajaran Pai Di Smp Pgri Betung." (Skripsi). Other thesis, UIN Raden Fatah Palembang 2016.

Arikunto, Suharsimi Prosedur Penelitian Suatu Pendekatan Praktek,(Jakarta: PT. Rineka Cipta, 2002, Cet. XII)

Arsyad, Azhar, Media Pembelajaran, Edisi Revisi, Cetakan ke- 17, (Jakarta, Rajawali Pers, 2014

Badaruddin, Achmad Peningkatan Motivasi Belajar Siswa melalui Konseling Klasikal, Abe

Kreatifindo Padang Sumatera Barat 2015

Daryanto, Media Pembelajaran Edisi Ke-2

Revisi, Gava MediaYogyakarta 2016

Danim, Sudarwan Menjadi Peneliti Kualitatif Rancangan Metodologi, Presentasi, dan Publikasi Hasil Penelitian untuk Mahasiswa dan Penelitian Pemula Bidang Ilmu Sosial, Pendidikan, dan Humaniora,(Bandung: Remaja Rosdakarya,2002), Cet. I.

E. Smaldin, Sharon dkk. Intructional Technology and Media For Learning, (Jakarta: Kencan, 2012),

Haris, Abdul Pito, Pusdiklat Tenaga Teknis Pendidikan dan Keagamaan, Media 
Upaya Penggunaan Perangkat Multimedia Dalam Meningkatkan Motivasi Belajar SiswaSiswi Kelas VIII Pada Mata Pelajaran Sejarah Kebudayaan Islam Di Madrasah Tsanawiyah

Pembelajaran Dalam Perspektif AlQur'an, Volume: VI No. 2. Juli Desember 2018

Heri, Totong "Meningkatkan Motivasi Minat Belajar Siswa" Dalam Jurnal: Rausyan Fikr Jurnal Pemikiran \& Pencerahan Agama Islam, No.1, Volume 15, Maret 2019.

Husaini Usman dan Akbar Purnomo Setiadi, Metodologi Penelitian Sosial, (Jakarta: PT Bumi Aksara, 2009)

J. Moelong, Lexy, Metode Penelitian Kualitatif, (Bandung: PT Remaja Rosdakarya, 2016) Cet ke-35

Kadaruddin, Buku Referensi Media Dan Multimedia Pembelajaran, Penerbit Deepublish Yogyakarta 2016
Kompri, Motivasi Pembelajaran Perspektif Guru Dan Siswa, Bandung: PT Remaja Rosdakarya. 2018

Muhadjir, Noeng Metodologi Penelitian Kualitatif Edisi VI, (Yogyakarta: Rakesarasin, 2011)

Nana, Sudjana dkk, Media Pengajaran (Bandung: Sinar Baru Algen Sindo, 2001)

Rusli, Muhammad Dadang Hermawan, dan Ni Nyoman Supuwaningsih, Multimedia Pembelajaran yang Inovatif, CV Andi Offset J1. Beo 38-40, Yogyakarta 2017

Zulkifili, Media Pembelajaran, UWAN Jl. Cipto Mangunkusumo No.30 Paninggilan Utara Ciledug, Kota Tangerang 2018 
Upaya Penggunaan Perangkat Multimedia Dalam Meningkatkan Motivasi Belajar Siswa-Siswi Kelas VIII Pada Mata Pelajaran Sejarah Kebudayaan Islam Di Madrasah Tsanawiyah Al-Mu'in Kota Tangerang 